\title{
Occupational health and safety awareness in wood, wood products and mushroom production sector in Turkey
}

\author{
Osman Komut ${ }^{\mathrm{a}, *}$ (i), Şekip Şadiye Yaşar ${ }^{\mathrm{b}}$ (i), Mehmet Yaşar $^{\mathrm{b}}$ (i)
}

\begin{abstract}
The forest industry is one of the sectors where occupational accidents are the most common. In this study, it is aimed to reveal the differences in opinions of personnel in enterprises, which fall into Turkish wood, wood products and mushroom production group, concerning occupational health and safety. Within this framework, a questionnaire application was conducted based on face to face meeting in a total of 68 enterprises in Erzincan province. In the questionnaire, the 5-point likert rating scale was used in determination of agreement level to scale items containing 9 different opinions concerning occupational health and safety issue underlying demographic characteristics of personnel and features of enterprises. As the result of the study, it was detected that machinery maintenance frequencies are too far, necessary personal protective equipment is not supplied in time and basic occupational health and safety principle implementation has deficiencies. Besides, statistically significant differences $(\mathrm{p}<0.05)$ were identified between opinions of employees in relation to variances as age, marital status, department worked, total time of employment in the enterprise, machinery maintenance frequency that is applied, workplace change intervals and exposure to occupational accidents.
\end{abstract}

Keywords: Occupational health and safety, Timber products sector, Awareness, Small and medium sized enterprise

\section{Türkiye ağaç, ağaç ürünleri ve mantar üretim sektöründe iş sağlığı ve güvenliği farkındalı̆ğ}

\begin{abstract}
Özet: Orman endüstri sektörü, en fazla iş kazası meydana gelen sektörlerden biridir. Bu çalışmada, Türkiye ağaç, ağaç ürünleri ve mantar imalatı grubunda yer alan işletme çalışanlarının iş sağlığı ve güvenliği konusundaki görüş farklılıkları ortaya koyulmaya çalışılmıştır. Bu kapsamda, Erzincan ilinde toplam 68 işletmeye yüz yüze görüşme esasına dayalı anket uygulaması gerçekleştirilmiştir. Ankette, çalışanların demografik özellikleri ile işletmelerin bazı özellikleri temelinde, iş sağlığı ve güvenliğ konusunda 9 farklı görüş içeren ölçek maddelerine katılım oranlarının belirlenmesinde 5'li likert tipi derecelendirme ölçeği kullanılmıştır. Çalışma sonucunda, ağaç, ağaç ürünleri ve mantar imalatı sektöründe çalışanların eğitim düzeylerinin düşük olduğu ve orta yaş grubunda yer aldıkları görülmüştür. Diğer yandan sektörde, makine bakım sıklıklarının çok uzun olduğu ve gerekli kişisel koruyucu ekipmanların zamanında sağlanmadığı ve temel iş sağlığı ve güvenliği ilkelerinin uygulanmasında eksiklikler olduğu tespit edilmiştir. Bununla birlikte yaş, medeni durum, çalışılan departman, işyerindeki toplam çalışma süresi, uygulanan makine bakım sıklığı, işyeri değişim sıklığı ve iş kazalarına maruz kalma değişkenlerine ilişkin çalışanların iş sağlığı ve güvenliği hususundaki görüşleri arasında istatistiksel düzeyde anlamlı $(\mathrm{p}<0,05)$ farklılıklar olduğu tespit edilmiştir.

Anahtar kelimeler: İş sağlığı ve güvenliği, Kereste üretim sektörü, Farkındalık, Küçük ve orta ölçekli işletme
\end{abstract}

\section{Introduction}

International labour organization defines the work accident as "An occurrence arising out of, or in the course of, work which results in a fatal or non-fatal injury" (ILO, 2015). Occupational diseases are disease states that arise mostly from repeated activities because of the work's character and can show temporariness and continuity (Dirican and Bilgel, 1993). According to values of ILO, the weak and faulty occupational health practices correspond to roughly $4 \%$ of global gross domestic product, also one of the factors of 2.78 million accidents involving death occurring every year (ILO, 2018). "Occupational health and safety law- Turkish" with law no. 6331 was published in Turkey at Official Gazette on 30 June 2012 in accordance with the norms of ILO and international institutions and legal legislations were carried out in compliance with this law.

The furniture manufacturing industry is regarded as a hazardous branch of industry (Ma et al., 1991; ÇSGB, 2009; ILO, 2015). Wood powder, formaldehydes, varnish, paint, adhesive, various solvent based products and lightning, vibration, noise and ergonomic risk factor that have physical effects can be shown among factors that cause work accidents and occupational diseases in wood works sector (HSE, 2002; Kürklü et al., 2013; Tankut et al., 2014).

In managements which do wood cutting, the present hazards related with occupational health and safety have been determined as general hazards mechanical hazards,

\footnotetext{
$\triangle$ a Gümüşhane University, Gümüşhane Vocational School, Department of Forestry, Gümüşhane, Turkey

b Gümüşhane University Gümüşhane Vocational School, Design Department, Gümüşhane, Turkey

Citation (Atıf): Komut, O., Yaşar, Ş.Ş., Yaşar, M., 2020. Occupational health and safety awareness in wood, wood products and mushroom production sector in Turkey. Turkish Journal of Forestry, 21(3): 260-266. DOI: $10.18182 /$ tjf. 741635 
exposure to noise, exposure to wood powder and the lack of personal protective equipment (PPE) usage (Akça, 2015).

In a study conducted towards the workers in furniture production sector in Sakarya Province, the circumstances in which employees were exposed to work accidents and occupational disease were inspected and the occurrence rate of work accidents and occupational disease were stated to be above the Turkey overall. The main matters that the employees working in furniture sector are most disturbed by are untidiness, mess, noise, ambient temperature, gases, dust, lack of sufficient warning signs and hand tools and machines which are old or don't have regular maintenance period (Gedik and Illhan, 2014). Aaltonen (1996) studied the work accidents at 18 furniture factories in a period of 1 year, among 214 work accidents with lost time, 2 of them resulted in the loss of fingertip. The disabling injury rate was $14.4 \%$ per year.

The furniture production sector with a nace code of 31 ranks in the hazardous class according to "hazard classes list announcement concerning the occupational health and safety" (ÇSGB, 2009). According to records of the Social Security Institution (SGK), the total number of the occupational disease is 6 recorded in this sector between years 2014-2016, the incapacity to work situations with respect to work accident cases in those years are shown in Figure 1 (SGK, 2018).

The purpose of this study, wood, wood products and the determination of the factors threatening the health of employees in the manufacturing sector mushrooms and occupational health and safety is to determine the level of awareness. Identifying occupational health and safety awareness factors in the sector, which is one of the sectors with the most occupational accidents and occupational diseases, will be effective in taking preventive measures.

\section{Material and methods}

The data collection tool was applied to a total of 100 employees in 27 manufacturers of wood, wood works and mushroom production located in Erzincan province.

This study was conducted in the small and medium sized forest products industry enterprises which produce wood, wood work and mushroom and operate in the city center of Erzincan. Since the activity area in the sub sector of forest products industry is spread across the country and consists of small and medium sized, it differs from other industry areas. The data collection tools of the study constitute of work place observations and surveys applied with face to face interview method.
In total, 68 participants in 27 different managements were reached in the study area where 32 managements and 100 employees are registered (SGK, 2016). Minimum conditions have been reached with the 25 workplace and 49 participants according to the Equation (1) (Yazıcıoglu and Erdoğan, 2004; Baş, 2006). In the calculation in question, the significance level was accepted as $5 \%(\mathrm{p})$, the sampling error as $10 \%(\mathrm{~d})$, both $\mathrm{p}$ and $\mathrm{q}$ were accepted as 0.5 and reliability coefficient as 1.96 , assuming different opinions in the study population.

$$
\mathrm{n}=\left[\mathrm{N} \cdot \mathrm{t}^{2} \cdot \mathrm{p} \cdot \mathrm{q}\right] /\left[\mathrm{d}^{2} \cdot(\mathrm{N}-1)+\mathrm{t}^{2} \cdot \mathrm{p} \cdot \mathrm{q}\right]
$$

A total of 28 questions and 9 propositions measuring the agreement of the participant through 5-point Likert scale structure have been used as a data collection tool.

The statistical analysis of the data was conducted with the help of the SPSS 20.0 application. In the case of the results of data homogeneity test being $p>0.05$, the factor distributions have been accepted as normal. However, the Central Limit Theorem states that the number of samples as $\geq 30$ is sufficient for the normal distribution suitability of data (Kalayc1, 2010). According to this, the data were first subjected to the homogeneity test and the significance level for the 8 propositions was calculated as $\mathrm{p}<0.05$. Nevertheless, parametric tests have been decided to be used since the number of samples was 68. In this context, Independent Two Sample T-Test was used in comparisons with two independent variables and One-Way Variance Analysis (ANOVA) was used in comparisons with more than two independent variables in order to identify differences of views among participants. Arithmetic mean and percentage values of the data were calculated by using Microsoft Excel package program.

\section{Results and discussion}

Kaiser-Meyer- Olkin (KMO) validity test was applied to test the suitability of the factor analysis and the validity of the data obtained by data collection tools (Büyüköztürk, 2006; Kalayc1, 2010). KMO validity test was conducted on the data obtained in the study, KMO coefficient was calculated as 0.654 . As the obtained value is $>0.50$, the sufficient validity to obtain was observed. On the other hand, because Barlett's test results were found to be significant with $95 \%$ reliability level $(\mathrm{p}=0.000)$, the existence of the high-level correlation between variables can be stated (Kalayc1, 2010).

$$
\begin{aligned}
& \square \text { Can not execute work for } 5+\text { days } \\
& \square \text { Can not execute work for } 4 \text { days } \\
& \square \text { Can not execute work for } 3 \text { days } \\
& \square \text { Can not execute work for } 2 \text { days } \\
& \square \text { Can not work on the day of accident } \\
& \square \text { Can work on the day of accident }
\end{aligned}
$$

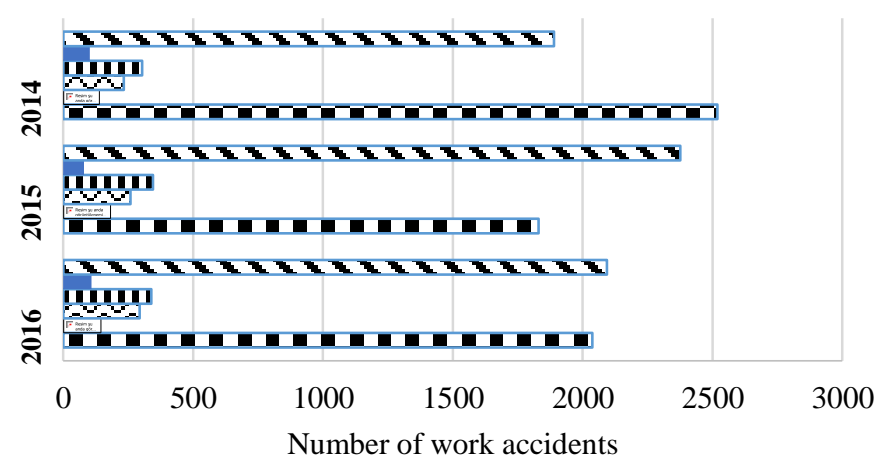

Number of work accidents

Figure 1. Incapacity to work cases originating from furniture production industry work accidents in years 2014 to 2016 
The reliability analysis of the research data was calculated as 0.787 with the Cronbach Alpha method. This result showed that the reliability level of the scale used was sufficient (Tavşancıl, 2014).

In the study, it was observed participants are predominantly 45 years old and younger, and $57 \%$ of them are married also the same proportion of them are high school graduate (Table 1). The ratio of employees with associate degree was found as $4 \%$, there are no employees with bachelor's degree among participants. In the study, the ratio of participants who work in the production of wood, wood works and mushroom was $4 \%$, the ratio of personnel with term of employment until 5 years was $76 \%$, the ratio for employees with employment terms between 5-10 years was determined as $19 \%$ (Table 1).

It has been identified that $18 \%$ of participants change their work in durations which are less than a year, 25\% between 1 and 2 years, $26 \%$ between 3-5 years, $10 \%$ between $5-7$ and $22 \%$ in longer durations.

As it is seen in Table 2, statistically significant differences $(p<0.05)$ between the views of employees in different age groups concerning the occupational health and safety propositions have been identified. In general, as the ages of employees are raising, it is found out that they think they have more knowledge about the work conducted, raw material used and machines. On the other hand, participants have concerns with regard to workload causing health problems for workers. The studies reached at the literature prove that the increase in work load have important effects on the accident risk (Dwyer and Raftery, 1991; Uysal et al., 2005). The proposition which doesn't have significant difference of views between age groups but has the lowest agreement average is that employees have the adequate knowledge concerning occupational health, legal right and responsibilities. In general, it has been identified that participants come to an agreement in that they don't know their legal rights and responsibilities. It is reported that the age variable in the furniture production and other forest industry sectors causes differences in perception about occupational health and safety (Aydın et al., 2015; Yıldırım et al., 2015). On the other hand, it has been stated that throughout the industry sector the sensibility for workload and working conditions increases with the increase in workers' age (Graveling, 2011; Güler, 2015; Ofluoğlu and Albar, 2017).

Table 1. The distribution of participants according to some variables

\begin{tabular}{lccc}
\hline Variable & Sub group & Frequency & Ratio (\%) \\
\hline \multirow{4}{*}{ Age } & $18-25$ & 22 & 32 \\
& $26-35$ & 12 & 18 \\
& $36-45$ & 31 & 46 \\
\multirow{2}{*}{ Marital status } & $46-55$ & 3 & 4 \\
\hline \multirow{3}{*}{ Education background } & Married & 39 & 57 \\
& Single & 29 & 43 \\
\hline \multirow{4}{*}{ Term of employment } & Primary education & 26 & 38 \\
(Year) & Hssociate degree & 39 & 57 \\
& $0-1$ & 9 & 4 \\
\hline
\end{tabular}

With the raise in total term of employment at the workplace, participants think that they have more knowledge about the work done, the machinery-equipment used and raw materials (Table 3). It can also be inferred from Table 3 that with the increase in total time of employment and decrease in frequency for work change; the idea that the endured work load poses danger for human health becomes widespread although the view that gradually more knowledge is possessed about occupational health and safety, gains importance, even for the workers with the longest employment time, the sufficiency of the knowledge level causes uncertainties. On the other hand, the frequency of work change of participants is observed to be high from the Table 3. The dissatisfaction with work and insecurity are affirmed to be crucial factors for the increase in the frequency of work change (Eğinli, 2009). Unsafe and inappropriate working conditions in terms of health are known to have a noteworthy influence on the performance of the employee and occupational health and safety (Turan, 2013).

Participants were asked to determine work accidents causes considering the priority ranking from 1 to 5 and the obtained data were weighted according to the priority order (Figure 2). While the personal reasons have been identified as the most important reason for work accident; technical reasons, excessive work load, the inspection insufficiency at the workplace and lack of training in occupational health and safety have been determined as priority reasons for work accidents. On the other hand, the ratio for exposure to accident has been identified as $35 \%$ with 24 participants. The accident risk for $50 \%$ of participants who were exposed to work accident has been found as 2 or more. It has been reported that the risk of accidents in furniture enterprises is higher than other sectors and the most important causes of accidents are based on personal reasons such as carelessness and neglect (Uysal et al., 2005). Again, in a similar manner, it has been expressed that the accidents in general industrial activities arise from factors related to human with a ratio of 88\% (Kepir, 1983).

18 of the injuries occurring after work accidents have been determined to occur as hand and finger injuries, 3 of them as torso injuries and 3 of them as arm injuries. The view that the injuries in the sector have occurred in general as mild and medium intensity injuries and the severe injury level is relatively low, has been supported with the studies in the literature (Uysal et al., 2005). 
Table 2. One-way Variance analysis results according to participants' age variable

\begin{tabular}{|c|c|c|c|c|c|}
\hline The propositions concerning the occupational health and safety & Age & $\mathrm{N}$ & $\mathrm{M}$ & $\mathrm{F}$ & Sig. \\
\hline \multirow{5}{*}{ I have adequate knowledge about machines and raw materials used at the workplace } & $18-25$ & 22 & 2.681 & \multirow{5}{*}{8.017} & \multirow{5}{*}{$0.000 *$} \\
\hline & $26-35$ & 12 & 3.500 & & \\
\hline & $36-45$ & 31 & 4.000 & & \\
\hline & 46-55 & 3 & 4.000 & & \\
\hline & Total & 68 & 3.485 & & \\
\hline \multirow{5}{*}{ I have adequate knowledge about the work I'm carrying out. } & $18-25$ & 22 & 2.818 & \multirow{5}{*}{10.708} & \multirow{5}{*}{$0.000^{*}$} \\
\hline & $26-35$ & 12 & 3.500 & & \\
\hline & $36-45$ & 31 & 4.290 & & \\
\hline & 46-55 & 3 & 5.000 & & \\
\hline & Total & 68 & 3.705 & & \\
\hline \multirow{5}{*}{ The quality level of our products is high } & $18-25$ & 22 & 3.545 & \multirow{5}{*}{10.143} & \multirow{5}{*}{$0.000 *$} \\
\hline & $26-35$ & 12 & 3.250 & & \\
\hline & $36-45$ & 31 & 4.419 & & \\
\hline & 46-55 & 3 & 5.000 & & \\
\hline & Total & 68 & 3.955 & & \\
\hline \multirow{5}{*}{ The protectiveness of equipment we use are sufficient } & $18-25$ & 22 & 3.590 & \multirow{5}{*}{9.593} & \multirow{5}{*}{$0.000 *$} \\
\hline & $26-35$ & 12 & 3.000 & & \\
\hline & $36-45$ & 31 & 4.322 & & \\
\hline & $46-55$ & 3 & 4.000 & & \\
\hline & Total & 68 & 3.838 & & \\
\hline \multirow{5}{*}{ The workload at the workplace is not in a level that can risk my health. } & $18-25$ & 22 & 3.136 & \multirow{5}{*}{4.431} & \multirow{5}{*}{$0.007 *$} \\
\hline & $26-35$ & 12 & 2.500 & & \\
\hline & $36-45$ & 31 & 3.354 & & \\
\hline & $46-55$ & 3 & 1.000 & & \\
\hline & Total & 68 & 3.029 & & \\
\hline \multirow{5}{*}{$\begin{array}{l}\text { Environment and Work conditions at the workplace are suitable in terms of occupational } \\
\text { health and safety }\end{array}$} & $18-25$ & 22 & 3.727 & \multirow{5}{*}{18.626} & \multirow{5}{*}{$0.000 *$} \\
\hline & $26-35$ & 12 & 2.500 & & \\
\hline & $36-45$ & 31 & 3.838 & & \\
\hline & $46-55$ & 3 & 4.000 & & \\
\hline & Total & 68 & 3.573 & & \\
\hline \multirow{5}{*}{$\begin{array}{l}\text { The machines at the workplace are placed correct and the size of the workplace is sufficient } \\
\text { for a smooth production. }\end{array}$} & $18-25$ & 22 & 3.863 & \multirow{5}{*}{13.839} & \multirow{5}{*}{$0.000^{*}$} \\
\hline & $26-35$ & 12 & 4.000 & & \\
\hline & $36-45$ & 31 & 4.032 & & \\
\hline & $46-55$ & 3 & 1.000 & & \\
\hline & Total & 68 & 3.838 & & \\
\hline \multirow{5}{*}{$\begin{array}{l}\text { I have sufficient knowledge about my legal rights and responsibilities as well as occupational } \\
\text { health and safety }\end{array}$} & $18-25$ & 22 & 1.727 & \multirow{5}{*}{1.935} & \\
\hline & $26-35$ & 12 & 2.250 & & \\
\hline & $36-45$ & 31 & 2.032 & & 0.133 \\
\hline & $46-55$ & 3 & 3.000 & & \\
\hline & Total & 68 & 2.014 & & \\
\hline & $18-25$ & 22 & 4.318 & & \\
\hline & $26-35$ & 12 & 3.000 & & \\
\hline The workbench and other work areas at the workplace are compatible with body sizes of & $36-45$ & 31 & 4.354 & 14.241 & $0.000 *$ \\
\hline & $46-55$ & 3 & 5.000 & & \\
\hline & Total & 68 & 4.132 & & \\
\hline
\end{tabular}


Table 3. One-way variance analysis results according to total term of employment and frequency of workplace change variables for participants at the workplace

\begin{tabular}{|c|c|c|c|c|c|c|c|c|c|c|}
\hline $\begin{array}{l}\text { The propositions towards } \\
\text { the occupational health and } \\
\text { safety }\end{array}$ & $\begin{array}{c}\text { Term of } \\
\text { employment } \\
\text { (year) }\end{array}$ & $\mathrm{N}$ & M & $\mathrm{F}$ & Sig. & $\begin{array}{c}\text { Workplace } \\
\text { change frequency } \\
\text { (year) }\end{array}$ & $\mathrm{N}$ & M & $\mathrm{F}$ & Sig. \\
\hline \multirow{6}{*}{$\begin{array}{l}\text { I have adequate knowledge } \\
\text { about machines and raw } \\
\text { materials used at the } \\
\text { workplace }\end{array}$} & $0-1$ & 9 & 2.6667 & \multirow{6}{*}{9.064} & \multirow{6}{*}{$0.000^{*}$} & $0-1$ & 12 & 2.2500 & \multirow{6}{*}{20.335} & \multirow{6}{*}{$0.000^{*}$} \\
\hline & $1-3$ & 23 & 3.2609 & & & $1-3$ & 17 & 2.8235 & & \\
\hline & $3-5$ & 20 & 3.2000 & & & $3-5$ & 17 & 3.7647 & & \\
\hline & $5-10$ & 13 & 4.7692 & & & $5-10$ & 7 & 4.5714 & & \\
\hline & $>10$ & 3 & 40000 & & & $>10$ & 15 & 4.4000 & & \\
\hline & Total & 68 & 3.4853 & & & Total & 68 & 3.4853 & & \\
\hline \multirow{6}{*}{$\begin{array}{l}\text { I have adequate knowledge } \\
\text { about the work I'm } \\
\text { carrying out }\end{array}$} & $0-1$ & 9 & 3.0000 & \multirow{6}{*}{8.877} & \multirow{6}{*}{$0.000 *$} & $0-1$ & 12 & 2.7500 & \multirow{6}{*}{15.310} & \multirow{6}{*}{$0.000^{*}$} \\
\hline & $1-3$ & 23 & 3.3913 & & & $1-3$ & 17 & 3.0000 & & \\
\hline & $3-5$ & 20 & 3.3500 & & & $3-5$ & 17 & 3.5882 & & \\
\hline & $5-10$ & 13 & 5.0000 & & & $5-10$ & 7 & 5.0000 & & \\
\hline & $>10$ & 3 & 5.0000 & & & $>10$ & 15 & 4.8000 & & \\
\hline & Total & 68 & 3.7059 & & & Total & 68 & 3.7059 & & \\
\hline \multirow{6}{*}{$\begin{array}{l}\text { The quality level of our } \\
\text { products is high }\end{array}$} & $0-1$ & 9 & 3.6667 & \multirow{6}{*}{5.763} & \multirow{6}{*}{$0.001 *$} & $0-1$ & 12 & 3.250 & \multirow{6}{*}{8.861} & \multirow{6}{*}{$0.000 *$} \\
\hline & $1-3$ & 23 & 3.8261 & & & $1-3$ & 17 & 3.5882 & & \\
\hline & $3-5$ & 20 & 3.5500 & & & $3-5$ & 17 & 3.8235 & & \\
\hline & $5-10$ & 13 & 4.7692 & & & $5-10$ & 7 & 4.5714 & & \\
\hline & $>10$ & 3 & 5.0000 & & & $>10$ & 15 & 4.8000 & & \\
\hline & Total & 68 & 3.9559 & & & Total & 68 & 3.9559 & & \\
\hline \multirow{6}{*}{$\begin{array}{l}\text { The protectiveness of } \\
\text { equipment we use are } \\
\text { sufficient }\end{array}$} & $0-1$ & 9 & 3.6667 & & & $0-1$ & 12 & 3.2500 & & \\
\hline & $1-3$ & 23 & 3.4348 & & & $1-3$ & 17 & 3.4118 & & \\
\hline & $3-5$ & 20 & 3.7500 & 6152 & $\Omega \cap \cap \cap *$ & $3-5$ & 17 & 4.0588 & 5246 & $0001 *$ \\
\hline & $5-10$ & 13 & 4.7692 & 0.152 & 0.000 & $5-10$ & 7 & 4.574 & 5.240 & $0.001 \%$ \\
\hline & $>10$ & 3 & 4.0000 & & & $>10$ & 15 & 4.2000 & & \\
\hline & Total & 68 & 38382 & & & Total & 68 & 3.8382 & & \\
\hline & $0-1$ & 9 & 3.3333 & & & $0-1$ & 12 & 3.0000 & & \\
\hline & $1-3$ & 23 & 2.5652 & & & $1-3$ & 17 & 2.5882 & & \\
\hline The workload at the & $3-5$ & 20 & 3.0500 & & & $3-5$ & 17 & 3.4118 & & \\
\hline Workplace is not in a level & $5-10$ & 13 & 4.0769 & 0.420 & $0.000^{2}$ & $5-10$ & 7 & 3.7143 & 1.524 & 0.206 \\
\hline & $>10$ & 3 & 1.0000 & & & $>10$ & 15 & 2.8000 & & \\
\hline & Total & 68 & 3.0294 & & & Total & 68 & 3.0294 & & \\
\hline & $0-1$ & 9 & 4.0000 & & & $0-1$ & 12 & 3.2500 & & \\
\hline Environment and Work & $1-3$ & 23 & 3.4783 & & & $1-3$ & 17 & 3.8235 & & \\
\hline conditions at the workplace & $3-5$ & 20 & 3.3000 & & 0086 & $3-5$ & 17 & 3.5294 & & 0371 \\
\hline are suitable in terms of & $5-10$ & 13 & 3.7692 & 2.142 & 0.080 & $5-10$ & 7 & 3.5714 & 1.086 & 0.371 \\
\hline safety & $>10$ & 3 & 4.0000 & & & $>10$ & 15 & 3.6000 & & \\
\hline & Total & 68 & 3.5735 & & & Total & 68 & 3.5735 & & \\
\hline & $0-1$ & 9 & 4.3333 & & & $0-1$ & 12 & 3.5000 & & \\
\hline & $1-3$ & 23 & 3.7391 & & & $1-3$ & 17 & 3.8235 & & \\
\hline workplace are placed & $3-5$ & 20 & 3.7500 & & & $3-5$ & 17 & 4.0588 & & (2) \\
\hline correct and the size of the & $5-10$ & 13 & 4.4615 & 14.99 & $0.000^{*}$ & $5-10$ & 7 & 4.4286 & 1.449 & 0.228 \\
\hline workplace is sumcient for a & $>10$ & 3 & 1.0000 & & & $>10$ & 15 & 3.6000 & & \\
\hline & Total & 68 & 3.838 & & & Total & 68 & 3.838 & & \\
\hline & $0-1$ & 9 & 1.333 & & & $0-1$ & 12 & 2.250 & & \\
\hline I have sufficient knowledge & $1-3$ & 23 & 1.696 & & & $1-3$ & 17 & 1.8235 & & \\
\hline about my legal rights and & $3-5$ & 20 & 2.1000 & & & $3-5$ & 17 & 1.4118 & & \\
\hline responsibilities as well as & $5-10$ & 13 & 2.3846 & 2.697 & $0.039^{*}$ & $5-10$ & 7 & 3.5714 & 9.489 & $0.000^{*}$ \\
\hline safety & $>10$ & 3 & 3.0000 & & & $>10$ & 15 & 2.0000 & & \\
\hline & Total & 68 & 2.0147 & & & Total & 68 & 2.0147 & & \\
\hline & $0-1$ & 9 & 4.0000 & & & $0-1$ & 12 & 3.5000 & & \\
\hline The workbench and other & $1-3$ & 23 & 4.3043 & & & $1-3$ & 17 & 4.4118 & & \\
\hline work areas at the workplace & $3-5$ & 20 & 3.4500 & 8668 & $\Omega 0 \cap 0 *$ & $3-5$ & 17 & 3.7059 & 6065 & $0 \Omega 0 \cap *$ \\
\hline are compatible with body & $5-10$ & 13 & 4.7692 & 8.068 & $0.000^{*}$ & $5-10$ & 7 & 4.5714 & 0.065 & $0.000^{*}$ \\
\hline sizes of employees & $>10$ & 3 & 5.0000 & & & $>10$ & 15 & 4.6000 & & \\
\hline & Total & 68 & 4.1324 & & & Total & 68 & 4.1324 & & \\
\hline
\end{tabular}

N: Number - M: Mean - F: Test statistic value - $* \mathrm{p}<0.05$ 
$24 \%$ of participants have declared that they aren't given any (PPE), $76 \%$ have stated that PPE is provided in time. The most used PPE are ranked as protective glove, work clothing, protective mask and protective footwear (Figure $3)$. However, generally the workers in wood work sector aren't fully aware of the existing danger, and activities are stated to be conducted without using PPE (Turan, 2013). To decrease the rate of work accidents in industrial activities, it is regarded to be necessary that employees should receive trainings on PPE and these trainings should be repeated in periodic durations (Atılgan et al., 2015). Occupational health and safety in small-scale businesses in Turkey are inadequate measures to be attached to many different reasons (Akyüz et al., 2019). On the other hand, occupational health and safety awareness is reported to be low compared to other forest industry sectors, especially in timber industry (Yıldırım et al., 2018).

It has been understood that $74 \%$ of workplaces where the study was conducted doesn't have the adequate warning signs, although $91 \%$ of workplaces doesn't have the personnel that can perform machinery maintenance and repair, $90 \%$ doesn't carry out machinery equipment starting controls (Table 4). Again, it can be deduced from the table 4 that emergency and evacuation drills, which are among fundamental components of occupational health and safety, are not conducted $(82 \%)$.

The lack of inspection at the enterprise
The lack of inspection at the workplace
Excessive work load

Machines and equipment aren't suitable for personal protection

The Government doesn't provide the necessary supervisions

Environmental reasons

Lack of training of employee in occupational health and safety

$$
0
$$

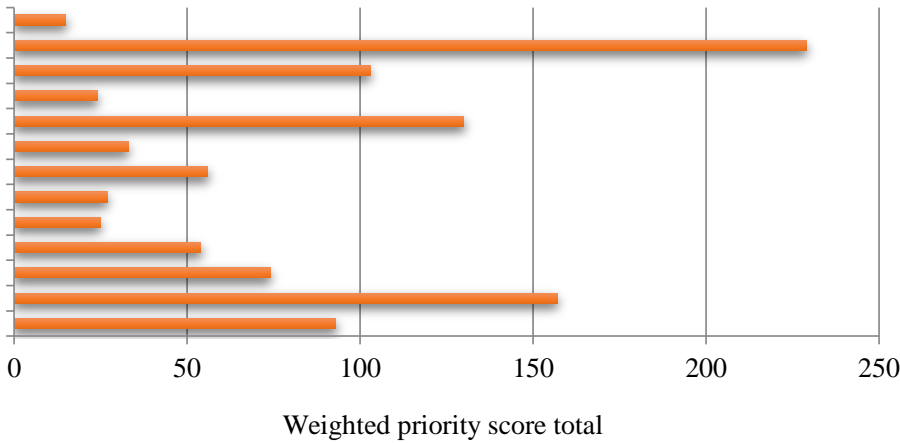

Figure 2. Reasons for work accidents according to views of participants

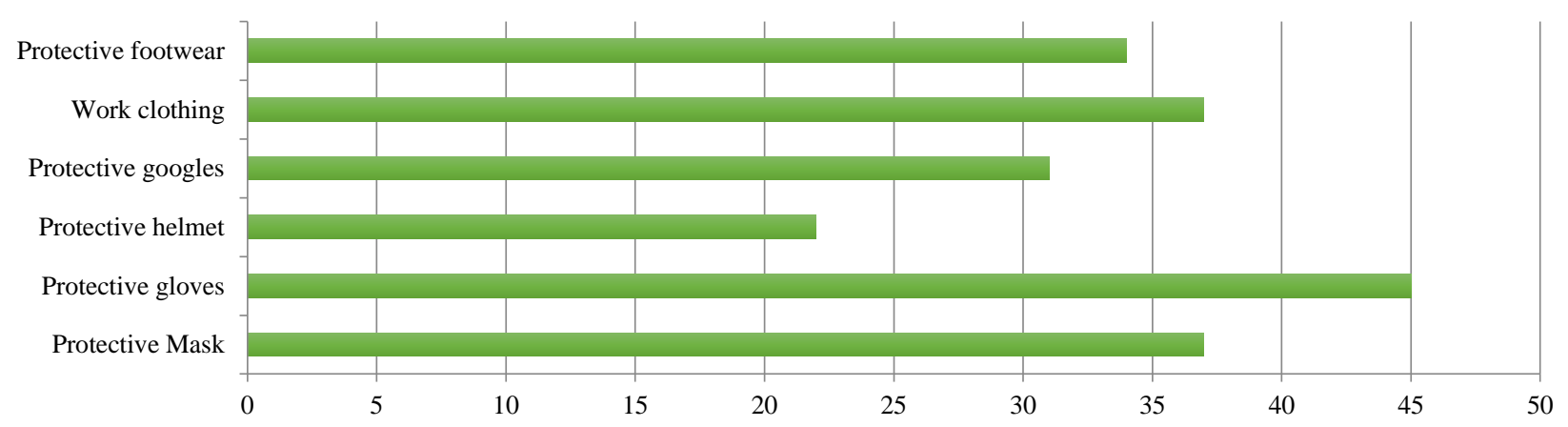

Figure 3. The most used personal projective gears (\%)

Table 4. The approach to some occupational health and safety principles

\begin{tabular}{|c|c|c|c|}
\hline Some Occupational Health and Safety Principles & Opinion & Frequences & Ratio (\%) \\
\hline \multirow{2}{*}{$\begin{array}{l}\text { The necessary warning signs towards the factors threatening the health and safety are found at the } \\
\text { workplace }\end{array}$} & Yes & 18 & 26 \\
\hline & No & 50 & 74 \\
\hline \multirow{2}{*}{ Machines and protective gear are checked before starting work at the workplace } & Yes & 7 & 10 \\
\hline & No & 61 & 90 \\
\hline \multirow{2}{*}{$\begin{array}{l}\text { The necessary precautions for risks concerning the usage of dangerous chemicals (cancerogenic } \\
\text { substances, irritants, varnish, paint, thinner, source gases) have been taken beforehand at the workplace }\end{array}$} & Yes & 35 & 51 \\
\hline & No & 33 & 49 \\
\hline \multirow{2}{*}{$\begin{array}{l}\text { Emergency and evacuation drills (fire, earthquake, chemical explosions) have been carried out at the } \\
\text { workplace }\end{array}$} & Yes & 12 & 18 \\
\hline & No & 56 & 82 \\
\hline \multirow{2}{*}{$\begin{array}{l}\text { There are technical personnel that can repair and make maintenance of the machineries at the workplace } \\
\text { and can defect measurements }\end{array}$} & Yes & 62 & 91 \\
\hline & No & 6 & 9 \\
\hline
\end{tabular}




\section{Conclusion}

In general, it is observed that low-education individuals find employment opportunities and lack of sufficient information and experience due to frequent workplace change increase the sensitivity in occupational health and safety. It is understood that occupational health and safety training and exercises are ignored due to economic concerns and PPEs which are needed are not supplied. In the business class sector, which has no appeal in terms of income and working conditions, the discrepancy between employee age and workload is an important problem. It has been observed that there are deficiencies in the provision and supervision of minimum conditions for occupational health and safety at workplaces. It is necessary to increase the controls on the implementation of legal regulations on occupational health and safety in small and medium-timber enterprises.

\section{Acknowledgements}

This research was presented as a verbal statement and published as a summary at the International Forest Products Congress (ORENKO 2018, 26-29 September 2018).

\section{References}

Aaltonen, M.V.P., 1996. Occupational injuries in the finnish furniture industry. Scandinavian Journal of Work, Environment \& Health, 22(3): 197-203.

Akça, K.İ., 2015. Identification of risks and hazards in establishments operating wood joinery and a case study. Thesis for Occupational Health and Safety Expertise, Ministry of the Labor and Social Security, Directorate General of Occupational Health and Safety, Ankara.

Akyüz, K.C., Yıldırım, İ., Akyüz, İ., Ersen, N., 2019. The forest products industry in work accidents and fatal work accidents in Turkey and examining the level of European Union countries. Artvin Çoruh University Faculty of Forestry Journal 20(2): 193207.

Atılgan, A., Ersen, N., Peker, H., Kahraman, N., 2015. Recommendations for the prevention of accidents and occupational diseases in Turkey furniture industry. Journal of Selcuk-Technic UMDK Special Issue: 664-683.

Aydın, A., Tiryaki, S., Üçüncü, K., Yıldırım, İ., 2015. The perception of workplace security climate in forest products industry. Suleyman Demirel University Journal of Engineering Sciences and Design, 3(3): 205-212.

Baş, T., 2006. How to Prepare Implement, Evaluate Survey?. Seçkin Publishing, 4th Edition, Ankara.

Büyüköztürk, Ş., 2006. Data Analysis Handbook. Pegem Akademi Publishing, 6. Edition, Ankara.

ÇSGB, 2009. Notice of list of dangerous classes related to occupational health and safety. Republic of Turkey Ministry of Labor and Social Security, 25 November 2009, Official Gazette Issue: 27417.

Dirican, R., Bilgel, N., 1993. Public Health (Community Medicine). Uludag University Faculty of Medicine Publications, Bursa.

Dwyer, T., Raftery, A.E., 1991. Industrial accidents are produced by social relationships of work: A sociological theory of industrial accidents. Applied Ergonomics, 22(3): 167-178.

Eğinli, A.T., 2009. Job satisfaction in employees: An investigation toward job satisfaction of public and private sector employees. Journal of Economics and Administrative Sciences, 23(3): 35-52.
Gedik, T., İlhan, A., 2014. A study on occupational health and safety in furniture manufacturers in Sakarya province. SDU Faculty of Forestry Journal, 15: 123-129.

Graveling, R., 2011. Occupational health and safety risks for the most vulnerable workers. European Parliament's Committee on Employment and Social Affairs, Brussels, European Parliament web page, (https://eige.europa.eu/docs/2024_IPOLEMPL_ET(2011) 464436_EN.pdf), Accessed: 28.04.2018.

Güler, Z., 2015. Occupational health and safety risks and measures implemented for the most vulnerable workers. Labour World Maga, 2: 117-134.

HSE, 2002. Hazardous Substances. Health and Safety Executive (HSE) web page, http://www.hse.gov.uk/woodworking/ hazard.htm, Accessed: 25.04.2018.

ILO, 2015. Investigation of occupational accidents and diseases. International Labour Organization web page, http://www.ilo.org/labadmin/info/pubs/WCMS_346714/lang-en/index.htm, Acccessed: 28.04.2018.

ILO, 2018. International newsletter on occupational health and safety. International Labour Organization web page, http://www.ilo.org/safework/info/publications/WCMS_616129 /lang--en/index.htm, Accessed: 25.04.2018.

Kalaycı, Ş., 2010. SPSS, Applied Multivariate Statistical Techniques. Asil Publishing, 5th edition, Ankara.

Kepir, H., 1983. Human factors and training in work accident, work accidents seminar reports with various dimensions and solution proposals. MPM Publishing, 284: 96-104.

Kürklü, G., Gürhan, G., Burgan, H.İ., 2013. Effect of noise in working life and evaluation in terms of construction technologies education. SDU International Technologic Science, 5: 22-35.

Ma, W.S.A., Wang, M.J.J., Chou, F.S., 1991. Evaluating the mechanical injury problem in the wood-bamboo furniture manufacturing industry. International journal of industrial ergonomics, 7(4): 347-55.

Ofluoğlu, G., Albar, B.Ö., 2017. Ageing labour-occupational health and safety problems and suggested solutions. HAK-ISS International Journal of Labour and Society 6(15): 335-360.

SGK, 2018. T.C. Social security institution statistics 2014-2016 annual statistics. http://www.sgk.gov.tr/wps/portal/tr/ kurumsal/istatistikler, Accessed: 07.06.2018.

SGK, 2016. Work accidents and occupational diseases statistics Republic of Turkey Social Security Institution. http://www.sgk.gov.tr/wps/portal/sgk/tr/kurumsal/istatistik/ sgk_istatistik_yilliklari, Accessed: 05.06.2018.

Tankut, A.N., Kurban, H., Melemez, K., 2014. Investigation on ergonomics effect of wood dust in forest produces enterprises. in II. National Mediterranean Forestry and Environment Symposium, 22-24 October, Isparta, Turkey, pp.785-794.

Tavşancıl, E., 2014. Measuring Attitudes and Data Analysis With SPSS. 5th Edition. Nobel Publishing, Ankara.

Turan, G., 2013. Assesment of major environmental effects encountered in furniture production processes in terms of labour health. MSc. Thesis, Namik Kemal University, Graduate School of Natural and Applied Sciences, Tekirdağ.

Uysal, B., Özçifçi, A., Kurt, Ş., 2005. Analysis of industrial accidents occured in small and medium-sized furniture manufacturing firms in Turkey. G.U. Journal of Science, 18(3): 439-451.

Yazıcıoğlu, Y., Erdoğan, S., 2004. SPSS Applied Scientific Research Methods. Detail Publishing, Ankara.

Yıldırım, İ., Akyüz, K.C., Akyüz, İ., Alevli, C., 2015. Determination of work satisfaction levels and work safety perception for the employees of furniture industry. Journal of Selcuk-Technic Online, 1(Special Issue): 171-184.

Yıldırım, İ., Akyüz, K., Akyüz, İ., Ersen, N., 2018. Investigation of employee perception towards occupational health and safety in forest products industry sector. Artvin Çoruh University Faculty of Forestry Journal, 19(2): 154-166. 